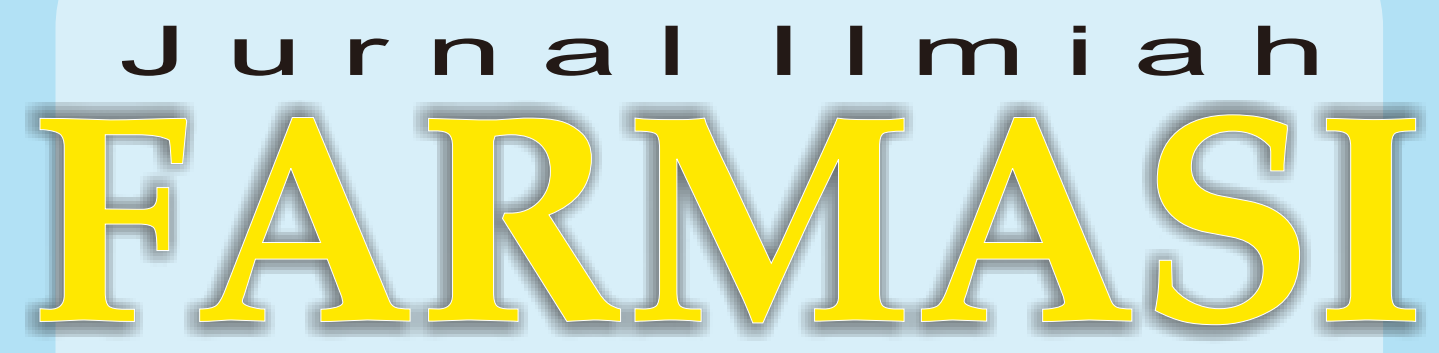

(Scientific Journal of Pharmacy) 
JURNAL ILMIAH FARMASI

(SCIENTIFIC JOURNAL OF PHARMACY)

PIMPINAN UMUM/ PENANGGUNG JAWAB

Dekan Fakultas Matematika dan Ilmu Pengetahuan Alam

Universitas Islam Indonesia

WAKIL PIMPINAN UMUM/ WAKIL PENANGGUNG JAWAB

Ketua Jurusan Farmasi FMIPA UII

\section{MITRA BESTARI}

1. Prof. Dr. Wiryatun Lestariana, Apt

2. Prof. Dr. Zullies Ikawati, Apt

3. Prof. Dr. Sudibyo Martono, Apt

4. Dr. Tedjo Yuwono, Apt

5. Prof. Dr. Dachriyanus, Apt

6. Prof. dr. Iwan Dwiprahasto, MMedSc, PhD

7. Prof. Dr. Lukman Hakim M.Sc., Apt

8. Prof. Dr. Achmad Fudholi, DEA, Apt

9. Prof. Dr. Ibnu Gholib Gandjar, DEA., Apt

\begin{tabular}{ll} 
& \multicolumn{1}{c}{ DEWAN EDITOR } \\
Ketua & : Saepudin, M.Si., Apt \\
Sekretaris & : Rochmy Istikharah, M.Sc., Apt. \\
Anggota & : Vitarani Dwi Ananda Ningrum, M.Si., Apt \\
& Okti R. Mafruhah, MSc., Apt \\
& Dimas Adhi Pradana, MSc., Apt. \\
& Fithria DA. Suryanegara, MSc., Apt. \\
& Ari Wibowo, S.Farm., Apt \\
& Arba Pramudita Ramadani, MSc., Apt. \\
& Oktavia Indrati, S.Farm., Apt.
\end{tabular}

Penerbit

Jurusan Farmasi Fakultas Matematika dan IImu Pengetahuan Alam Universitas Islam Indonesia

Alamat Penerbit Jurusan Farmasi FMIPA UII

Jl. Kaliurang Km. 14,4 Yogyakarta 55584

Telp. (0274) 896439 ext. 3047

Email: jif@uii.ac.id 


\title{
EFEK FRAKSI LARUT AIR EKSTRAK ETANOL 50\% KEMUNING (Murraya paniculata (L.) Jack) TERHADAP BERAT BADAN TIKUS BETINA DIET LEMAK TINGGI
}

\author{
Suwijiyo Pramono*, Agung Endro Nugroho*, Crisna Wardhani
}

${ }^{*}$ Fakultas Farmasi Universitas Gadjah Mada, Yogyakarta

\begin{abstract}
Obesity is considered as a health problem that can promote the risks of getting disease, being not active and death. In some developing countries, many traditional therapies are applied for some diseases, including obesity. Kemuning (Murraya paniculata (L.) Jack) has been commonly known as slimming potion. In present, kemuning leaf is used as ingredient of traditional medicine formula, indicated as slimming potion. Former researcher mentioned that $30 \%$ ethanol-bemusing extract had been able to reduce trigliserid content in the blood reduce cholesterol content in blood serum of male Wistar furrow white rat (Rattus norvegicus). This research is proposed to examine the effect of water soluble fraction of $50 \%$ ethanol-kemuning extract to female Wistar furrow white rat body weight which given high fat diet and to compare the effect with anorextica (mazindol). Tested animal are divided into 6 groups, each group contain 5 rats. Group I as negative control is given $0,5 \%$ CMC Na solution. Group II as positive control is given $0,27 \mathrm{mg} / \mathrm{kgBody}$ Weight mazindol suspension. Group III is given $50 \%$ ethanol-kemuning extract suspension with $475 \mathrm{mg} / \mathrm{kg} \mathrm{BW}$ dosage. Group IV is given watersoluble fraction suspension of kemuning extract dosage I that is $145 \mathrm{mg} / \mathrm{kgBW}$. Group V is given watersoluble fraction suspension of kemuning extract dosage II that is $295 \mathrm{mg} / \mathrm{kgBW}$. Group VI is given dose III that is $585 \mathrm{mg} / \mathrm{kgBW}$. The suspension is given orally with repeated dosage. Data collected are the increase of body weight, woof consumption and drinking consumption. Body weight and woof consumption increases are analyzed by one-way Anava with $90 \%$ significancy level. Research result shows that water soluble fraction of $50 \%$ ethanol-kemuning extract with $585 \mathrm{mg} / \mathrm{kgBW}$ dosage and positive control (mazindol) are able to obstruct rat body weight increase significancy $(p<0,10)$ compared to negative control group.
\end{abstract}

Keys word : Murraya paniculata (L.) Jack, obesity, antiobesity 